\title{
Decision and opinion of women in various home related activities
}

\author{
SEEMAPRAKALPA AND POOJA MISHRA
}

Received: 21.06.2014; Revised: 25.03.2015; Accepted: 28.03.2015

See end of the paper for authors' affiliations

\section{SEEMAPRAKALPA}

Department of Home Science Extension, Institute of Home Science, Dr. B.R. Ambedkar University, AGRA (U.P.) INDIA Email : prakalpass@gmail.com

\begin{abstract}
The trends of women's participation have been visibly reversed in recent years but the essential involvement of women in the rural development for their countries is not presently wide. Women in decision making and influential power are exception rather than the rule and they do not yet enjoy the equal status. Therefore, the present study was conducted to find out decision making level and opinion of women in various family related activities. Primary data were collected through interview schedule from 80 women of Parigwan village of Mainpuri district. Majority of respondents were found to be disagree regarding female education $(82.50 \%)$, female employment ( $70 \%$ ), right to take decision for the family $(77.50 \%)$, female worked independently $(51.25 \%)$, female decision regarding marriage $(90 \%)$ and female decision regarding casting of vote freely $(96.25 \%)$. While majority of the respondents were agree that female took part in religious activities $(72.50 \%)$ and female participation in political activities $(75 \%)$. Forty eight per cent of the respondents were found to be indifferent regarding equal status in the family while only 20 per cent respondents were of the opinion that equal status of female should be given in the family. They think that opinions of their husband are their decision because they are limited upto household duties and responsibilities. Therefore, there is a great need to counsel, provide guidance and aware about their abilities.
\end{abstract}

KEY WORDS: Women, Decision-making, Opinion

- HOW TO CITE THIS PAPER : Seemaprakalpa and Mishra, Pooja (2015). Decision and opinion of women in various home related activities. Asian J. Home Sci., 10 (1) : 65-72. 